\title{
Editarea comparativă a lexicoanelor slavo-române din secolul al XVII-lea: proiectul eRomLex ${ }^{\dagger}$
}

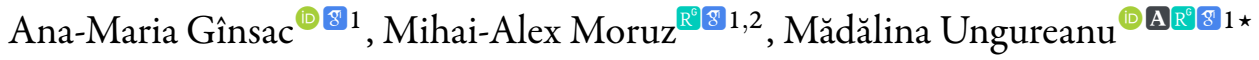 \\ ${ }^{1}$ Institutul de Cercetări Interdisciplinare, Departamentul de Științe Socio-Umane, Universitatea „Alexandru Ioan Cuza”, \\ Str. Al. Läpușneanu 26, 700057 Iași, România \\ ${ }^{2}$ Facultatea de Informatică, Universitatea „Alexandru Ioan Cuza”, Str. General Berthelot 16, 700483 Iaşi, România
}

\section{Despre articol}

Istoric:

Primit 29 septembrie 2021

Acceptat 19 octombrie 2021

Publicat 12 decembrie 2021

Cuvinte-cheie:

editarea textelor

eRomLex

lexicoane slavo-române

secolul al XVII-lea

lexicografie veche

\begin{abstract}
Rezumat
Articolul prezintă proiectul eRomLex, care are ca scop realizarea unei ediții digitale comparative a celor șase lexicoane slavo-române din secolul al XVII-lea ce au ca sursă Lexiconul slavon-rutean al lui Pamvo Berînda. După prezentarea succintă a cadrului general al apariției lexicoanelor și a stadiului actual al cercetării pe această temă, am urmărit liniile generale ale proiectului, argumentînd necesitatea și beneficiile unei astfel de prezentări a materialului lexicografic. În a doua parte, exemplificind cu extrase din materialul deja disponibil pe platforma proiectului, am arătat cîteva modalităţi în care autorii lexicoanelor românești valorifică informația existentă în sursă, atît la nivelul inventarului lexical, cît și la nivelul definițiilor.

Comparația a arătat că, în afară de Lex.Mard., cantitatea de material din lexicoanele românești este apropiată de cea din Lex.Ber.; scribii români nu preiau tot inventarul din sursă, dar adaugă lexeme în plus. În ceea ce privește definițiile, de obicei acestea sunt reduse față de cele din sursă, dar există și situații în care sunt adăugate în lexicoanele românești informații de diverse tipuri. Studiul lor exhaustiv, facilitat de platforma proiectului, poate oferi observații foarte interesante despre mentalitatea și educația din epoca alcătuirii lexicoanelor românești.
\end{abstract}

\section{Introducere}

Apariția și dezvoltarea lexicografiei românești în epoca premodernă urmează aceleași etape evolutive pe care acest domeniu le înregistrează și în alte culturi, iar aspectul determinant este diglosia: concurența dintre o limbă de cultură și una vulgară, care tinde să-i ia locul. În epoca veche, coexistența unei limbi de cultură, limba slavonă, și a unei limbi vulgare, dar care pretindea să capete statutul celeilalte, și diferențele fundamentale dintre cele două limbi au evidențiat necesitatea unor instrumente lexicografice bilingve, care să faciliteze transferul cultural dintre cele două limbi aflate în contact. Etapele dezvoltării instrumentelor lexicografice sînt cele cunoscute: de la glose la liste de cuvinte neordonate alfabetic și pînă la dicționarele propriu-zise, cu materialul ordonat alfabetic și de dimensiuni întinse. Prima etapă este ilustrată de glosele românești de pe marginea unor texte în limba slavonă („Glosele Bogdan”). O a doua etapă este caracterizată prin apariția unor glosare rudimentare și de mică întindere, redactate după modelul unor lucrări slavone similare: sînt cunoscute două astfel de lucrări din secolul al XVI-lea, „fragmentul de la Belgrad”, descoperit de E. Kałužniacki la Biblioteca Națională din Belgrad (Codicele miscellaneu nr. 321, fila 77, distrus în 1941) și reprodus în Kałužniacki (1894, p. 50-52), și „fragmentul de la Dragomirna”, conținut în ms. slavon nr. 149/1929 de la Mănăstirea Dragomirna, f. 161 (vezi Strungaru, 1966, p. 146; Mihăilă, 1972, p. 308). În ambele cazuri, cuvintele nu sînt ordonate alfabetic. În sfîrșit, a treia fază o reprezintă apariția dicționarelor bilingve propriu-zise, de întindere mare, cu intrările ordonate alfabetic.

\footnotetext{
${ }^{\dagger}$ Această lucrare a fost realizată cu sprijinul unui grant acordat de Ministerul Cercetării, Inovării și Digitalizării, CNCS/CCCDI - UEFISCDI, numărul proiectului: PN-III-P1-1.1-TE-2019-0517, în cadrul PNCDI III.

*Adresă de corespondență: madandronic@gmail.com.
} 
Ana-Maria Gînsac, Mihai-Alex Moruz, Mădălina Ungureanu

Din această categorie fac parte lexicoanele bilingve din secolul al XVII-lea: Anonymus Caransebesiensis, dicționar latin-român de la mijlocul secolului (vezi Anon.Car.); un lexicon italian-român, alcătuit cu puțin înainte de 1700, și Lexicon Marsilianum (cca 1678-1701), ambele editate de Tagliavini (1927, 1930); dicționarul latinesc-românesc al lui Teodor Corbea (vezi Corbea); la acestea se adaugă grupul celor șase dicționare slavo-române de care ne ocupăm. Desigur, în secolul al XVIII-lea, ca urmare a contactelor lingvistice și culturale și a mobilităţii din ce în ce mai accentuate, activitatea lexicografică se intensifică în Țările Române și se diversifică din punct de vedere lingvistic; dicționarele care au a doua limbă slavona din această perioadă sînt foarte puține, locul slavonei fiind luat de latină, de maghiară sau de o limbă romanică; vezi şi Seche (1966, p. 9-12).

\subsection{Lexicoanele slavo-române din secolul al XVII-lea}

Obiectul proiectului eRomLex îl constituie cele șase lexicoane slavo-române. Grupul lexicoanelor slavoromâne din secolul al XVII-lea este remarcabil din mai multe puncte de vedere. În primul rînd, prin numărul lor: șase lexicoane de mare întindere păstrate pînă astăzi, unele complete, altele lipsite de mici porțiuni; sînt printre primele dicționare românești propriu-zise. Apoi, prin strînsa relație dintre ele: toate sînt prelucrări după aceeași sursă, aflate evident în relație (incomplet clarificată) unele cu altele. De asemenea, toate par să vină din aceeași zonă geografică, a Munteniei. Evaluînd locul acestui grup de dicționare în cadrul larg al activității lexicografice românești din secolul al XVII-lea, este evident că ele constituie partea sa cea mai consistentă.

Sursa celor șase lexicoane o constituie Lexiconul slavon-ucrainean al lui Pamvo Berînda (1627, Kiev), cea mai importantă lucrare lexicografică din spaţiul slav din secolul al XVII-lea, lucrare cu cca 7000 de intrări grupate în două liste ordonate alfabetic, cu profiluri diferite: o listă de nume comune, cuvinte vechi, și alta de nume proprii și termeni savanți împrumutați din ebraică, greacă și latină, preluați din surse livrești (Stankiewicz, 1984, p. 152). Dicționarul, foarte popular în epocă, a jucat un rol important pentru lexicografia ucraineană, românească, rusă, bielorusă, polonă (Stankiewicz, 1984, p. 52).

Cele șase dicţionare bilingve slavo-române sînt toate păstrate în manuscris, datează din a doua jumătate a secolului al XVII-lea (cu o excepție, Lex.Mard., 1649) și sînt de mare întindere, fiind păstrate aproape complet (din Lex.3473 lipsesc filele aferente slovei A, iar din Lex.Staicu, de asemenea, citeva file de la aceeași slovă). Ca și sursa lor, sînt toate de tipul L2-L1 (limba-sursă este L2 pentru autori, în timp ce limba țintă este limba maternă, L1), spre deosebire de Anon.Car., care este L1-L2 (acest lucru indică faptul că au fost alcătuite în scopuri diferite). Din unele lipsesc fragmente. Se păstrează la Biblioteca Academiei Române din București, în afară de două (Lex.Pet. și Lex.Mosc.), păstrate la Biblioteca Naţională a Rusiei din Sankt Petersburg, respectiv la Arhiva Rusă de Stat a Actelor Vechi (RGADA). Două dintre ele (Lex.Staicu, Lex.3473) sînt urmate de o gramatică a limbii slavone în română, prelucrare, se pare, după Gramatica lui Meletie Smotrițki (Strungaru, 1960), iar unul de un Acatist al Maicii Domnului (Lex.1348); lucrările suplimentare sînt scrise de aceeași mînă. Nu toți autorii/copiștii lexicoanelor slavo-române sînt cunoscuți sau au fost identificaţi ${ }^{1}$.

\subsection{Stadiul actual al cercetării lexicoanelor slavo-române din secolul al XVII-lea}

Dintre cele șase lexicoane descrise, numai unul a fost editat pînă acum: lexiconul lui Mardarie, reprodus prin culegere cu caractere chirilice, fără transcriere în alfabet latin, de Crețu (1900). Dintre celelalte, au făcut obiectul unor studii mai amănunțite Lex.Staicu (Strungaru, 1966 îi demonstrează paternitatea prin comparație cu alte scrieri cunoscute ale cărturarului), Lex.Pet. (Bogdan, 1891 îl descrie și îi stabilește sursa), Lex.Mosc. (Ciobanu, 1914 descrie manuscrisul, identifică sursa și discută relația dintre text și sursă; Gînsac \& Ungureanu, 2019 formulează ipoteze despre filiațiile dintre Lex.Mosc. și celelalte lexicoane). Este posibil ca lipsa de interes faţă de editarea acestor lexicoane să se explice prin ideea vehiculată în literatura de specialitate că sunt foarte asemănătoare între ele și tributare sursei.

\footnotetext{
${ }^{1}$ Pentru o privire sintetică asupra celor șase lexicoane, vezi Gînsac \& Ungureanu (2018, p. 850-853) [și: consilr.info.uaic.ro].
} 
Prezentări ale tuturor lexicoanelor slavo-române și comparații punctuale găsim la Crețu (1900) și Mihăilă (1972). În general, cei interesați de aceste lexicoane au fost de acord cu descendența lor comună, iar filiațiile dintre ele au fost presupuse pe baza unor comparații de mică întindere (Mihăilă, 1972; Strungaru, 1966). Încă de la sfîrșitul secolului al XIX-lea a fost emisă ideea necesităţii unei ediții comparative (Bogdan, 1891; Mihăilă, 1972, p. 324), fără ca aceasta să fie realizată. Discuția este reluată de Gînsac \& Ungureanu (2018), care propun o stemma codicum diferită de cea de la Strungaru (1966) și formulează ipoteza unui intermediar pierdut, din care ar deriva toate, cu excepția Lex.Mard. Felea (2021) analizează Lex.Staicu în relaţie cu sursa și propune o reevaluare a relațiilor dintre lexicoane pe baza grafiei, a inventarului și a dispunerii listelor de termeni; tot el presupune, în cazul Lex.Staicu, valorificarea și a unui alt dicționar slavon, de alt tip, în listele de cuvinte suplimentare, dicționar care rămîne de identificat.

Dificultatea studierii lexicoanelor provine și din faptul că nu au fost editate pînă acum. Deși a fost emisă ideea necesității studiului lor comparativ, acesta nu a fost realizat: este dificilă studierea în paralel a șase texte de dimensiuni întinse, cu un bogat inventar lexical și cu problemele de dispunere care le caracterizează. În afară de editarea propriu-zisă, necesară prin simplul fapt că este vorba despre o parte importantă a patrimoniului cultural scris românesc (sînt, totuși, primele dicționare bilingve românești propriu-zise), sînt de rezolvat și alte probleme: filiațiile dintre ele, paternitatea fiecărui lexicon, integrarea lor în contextul cultural al epocii, tipologia, utilizatorii avuți în vedere, scopul alcătuirii lor, comparația cu sursa. Editarea lor este utilă pentru cercetările de istorie a limbii, a scrisului românesc, de istorie a lexicografiei, a traducerii, pentru dicționarul-tezaur al limbii române și, de asemenea, poate fi un prim pas pentru dezvoltarea unor ediții digitale viitoare ale unor texte vechi românești.

\section{Proiectul eRomLex}

Proiectul are ca obiectiv principal realizarea unei ediții comparative digitale a celor șase dicționare slavoromâne din secolul al XVII-lea, pornind de la faptul că ele au aceeași sursă, cu scopul de a evidenția caracteristicile acestei rețele lexicografice (filiațiile dintre lexicoane, modalitatea în care se raportează la sursă, inovațiile față de aceasta, probabilele lor utilizări) și de a pune în circulație textele propriu-zise. Mai concret, după o primă etapă, de fișare (cu transcriere interpretativă a definițiilor din lexicoanele românești și culegere a cuvintelor-titlu din Lex.Ber. și din cele românești, cu respectarea trăsăturilor grafice din fiecare lexicon), urmează etapa de prelucrare automată și aliniere a intrărilor din lexicoanele românești avînd ca pivot intrarea corespondentă din Lex.Ber.; în cazul în care aceasta lipsește (lexicoanele românești introduc intrări noi, nu întotdeauna aceleași), intrările vor fi aliniate între ele, avînd ca pivot Lex.Mosc., pe care îl considerăm cel mai apropiat de Lex.Ber. Alinierea se face pe baza gradului de similaritate a cuvîntuluititlu și pe baza localizării intrărilor din lexicoane; în acest sens, formatul de fișare presupune, atît în cazul Lex.Ber., cît și în cazul lexicoanelor românești, notarea filei, a coloanei și a numărului intrării pe coloană.

\subsection{De ce o ediție digitală?}

Am conceput ediția comparativă astfel întrucît o versiune digitalizată permite extragerea și compararea datelor într-un mod exhaustiv, aşa cum o ediție clasică (pe hîrtie) nu va permite niciodată. De asemenea, ediția digitală permite afișarea simultană a intrărilor din lexicoanele paralele, în scopul facilitării comparației dintre ele. Baza de date este astfel concepută încît să permită actualizarea continuă, cu alte texte, și legări la alte dicționare. Formatul permite corectura permanentă, de orice natură, și manipularea statistică a datelor.

La aceasta se poate obiecta faptul că un astfel de format permite accesul la conținutul dicționarelor, însă nu și vizualizarea lor într-o formă care să fie apropiată de cea din manuscris; cu alte cuvinte, permite o redare și o exploatare eficientă a conținutului lingvistic, însă are dezavantajul că obscurizează imaginea textului ca obiect - pentru filologia românească, reținerile față de o astfel de prelucrare și afișare a datelor este firească. De la afișarea liniară a informației în ediția pe hîrtie, cu care sîntem obișnuiți, trecem la afișarea lor simultană, iar „oglinda” paginii se pierde (afișarea intrărilor de pe o anumită pagină dintrun anumit lexicon va fi o opțiune în interfața de afișare, însă, desigur, nu va reflecta exact imaginea filei 
de manuscris). Totuși, prioritatea noastră este să putem examina conținutul lingvistic pentru a răspunde la întrebările și ipotezele formulate pînă acum, mai precis, pentru a avea o imagine asupra acestei rețele lexicografice și asupra atelierului de cărturari de la școala din Tîrgoviște; datele stocate pe platforma online pot fi extrase ulterior și valorificate în ediții clasice, pe hîrtie, individuale, ale acestor dicționare. O altă problemă pe care o presupune alegerea unei astfel de prelucrări este timpul de procesare crescut, o parte însemnată trebuie destinată validării manuale şi corectării erorilor de aliniere (în afară de corectura filologică propriu-zisă, referitoare la transcriere și culegere de text slavon).

\subsection{De ce o ediție comparativă?}

Ideea unei ediții comparative a lexicoanelor slavo-române din secolul al XVII-lea derivate din Lex.Ber. a fost enunțată de mai bine de un secol (Bogdan, 1891, p. 204) și reluată ulterior de Strungaru (1966), apoi de Mihăilă (1972, p. 323-324), care o consideră indispensabilă discutării raporturilor dintre lexicoane și, de asemenea, dintre ele și sursă; el propune o ordonare strict alfabetică a intrărilor; fiecare intrare ar trebui să primească un număr cu care să fie inclusă în lista generală, după modelul aplicat de Crețu (1900) la Lex.Mard.

Am conceput ediția comparativă conform aceleiași idei, aceea că ar fi singura modalitate prin care se pot examina relațiile dintre lexicoanele românești și, de asemenea, dintre acestea și sursă. Lexicoanele românești constituie o rețea, sînt legate între ele prin copiere, dar au şi componente separate, care pot aduce dovezi despre alcătuitorii lor, despre interesele acestora și, mai larg, despre activitatea de la școlile de slavonie din epocă. Unele fenomene dificil de explicat dacă ne raportăm la un singur lexicon pot fi

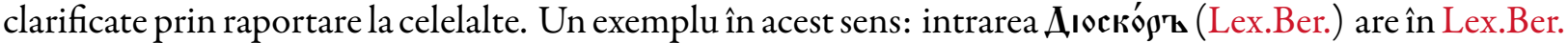

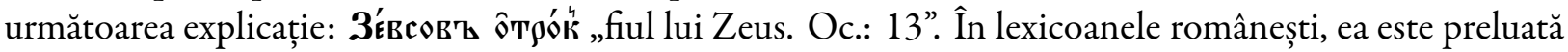
astfel:

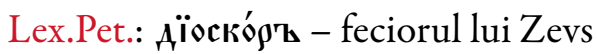

Lex.Staicu: Aїwckó - coconul lu Zevs

Lex.3473: Aї̈ско́ - fecior lui Zevs

Lex.Mosc.: Aї̈ско́ $\rho \mathbf{z}$ - fecior lui Zevs

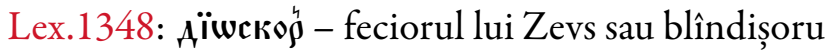

Lex.Mard.: -

Atrage imediat atenția explicația suplimentară din Lex.1348, care pare un supranume al lui Dioscor, mucenic sărbătorit la 13 octombrie, despre care găsim informații la Dosoftei, în Viața și petreacerea svinților:

„Într-aceastaș dzî, pomenirea svîntului măcenic Dioscor.

Acesta s-au nevoit în dzîlele împăratului Dioclitian. De rodul său era din Schinopoliți și era din sfat. Și socotind toate lucrurile aceștii vieți ca gunoaiele, numai pentru să-ș agonesască pre Domnul Hristos. Deci, luă îndrăznire și astătu naintea boiarinului Luchian. Și defăimîndu-l și batgiocurindu-l și nebăgînd samă nice-ntr-o nemică îngroziturile și răstiturile lui, nice măguliturile, că-l aducea și în foc, și în vîrteaje, și-n tot fealiul de munci. Și toate era o nemică și fără de nice o ispravă la svîntul; și i-au tăiatu-i capul”.

(DVs, p. 65)

Totuşi, acest eventual supranume nu este amintit nicăieri şi nici sinteza biografică de la Dosoftei nu pare să îl justifice. Comparația cu celelalte lexicoane indică sursa informației: cu două rînduri mai jos, în toate lexicoanele, cu excepția Lex.1348, apare intrarea corespunzătoare lui Aícкоč „potir” (Lex.Ber.):

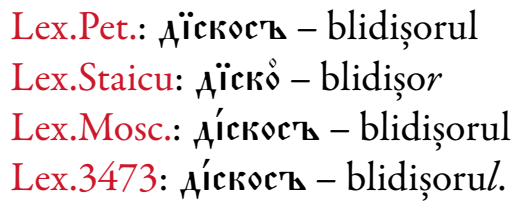


Așadar, notația suplimentară din Lex.1348 nu este o dovadă de utilizare a unei surse necunoscute, ci o eroare de copiere: scribul lexiconului, utilizînd, cel mai probabil, unul dintre celelalte lexicoane (unul în care forma este articulată), sare, atunci cînd copiază definiția, un rînd și copiază definiția de la Aï̄ckoc ‘u, pe

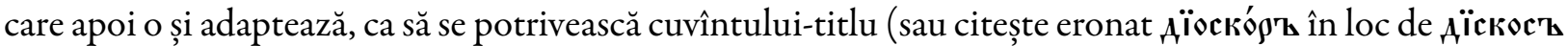
și crede că acelaşi cuvînt a fost notat de două ori, cu explicaţii diferite).

Expunerea paralelă facilitează discuția despre filiațiile dintre lexicoane, ca, de exemplu, în cazul următor, unde se observă coincidența de echivalare între, pe de o parte, Lex.Mard. și Lex.Staicu și, pe de alta, Lex.Mosc., Lex.Pet. și Lex.1348:

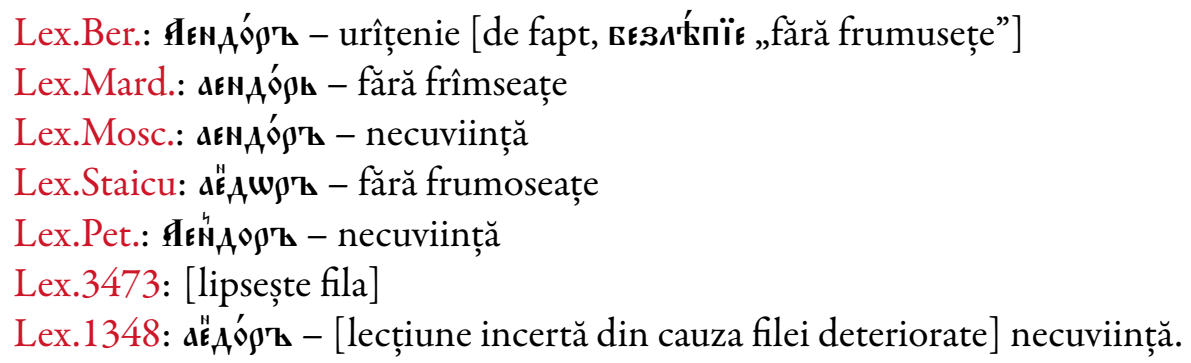

\section{Observații asupra modului de prelucrare a sursei}

Prelucrarea automată a lexicoanelor permite efectuarea de studii care să indice modalitatea în care autorii lor prelucrează materialul din sursă, atît din punct de vedere cantitativ (reducere/amplificare a inventarului intrărilor), cît și la nivelul structurii și al datelor furnizate în definiții. Dată fiind cantitatea foarte mare de material și faptul că în stadiul actual încă nu este disponibil corpusul integral, o analiză exhaustivă nu poate face obiectul articolului de față; ne-am propus aici ilustrarea unora dintre aceste modalități de valorificare a sursei.

\subsection{La nivel cantitativ (reducere/amplificare a inventarului)}

Fig. 1 arată, comparativ, numărul intrărilor din cele șapte lexicoane aliniate:

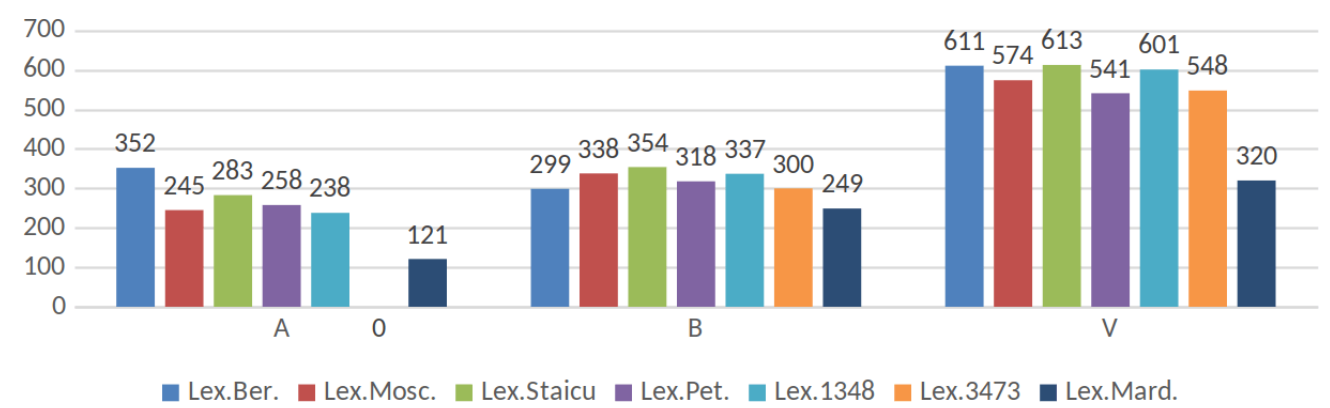

Figura 1: Numărul de intrări de sub slovele A, B, V

Se observă faptul că diferențele de inventar dintre lexicoane, sub fiecare slovă, nu sînt mari. Excepție face Lex.Mard., care este cel mai restrîns. Pe de altă parte, celelalte lexicoane au un inventar similar celui din Lex.Ber. din punct de vedere cantitativ.

Lexicoanele românești adaugă la inventarul reținut din Lex.Ber. un număr de intrări care variază (Fig. 2).

Se observă diferențe de tratament al inventarului lexical atît între lexicoane, cît și în ansamblu, de la o slovă la alta (concluziile la slova A sînt viciate de faptul că multe pagini din Lex.Staicu lipsesc). Lex.Mard. adaugă cel mai puțin, în cazul tuturor celor trei sub-inventare, în timp ce Lex.1348 are numărul cel mai mare de adaosuri, dar valorile sînt destul de similare. 


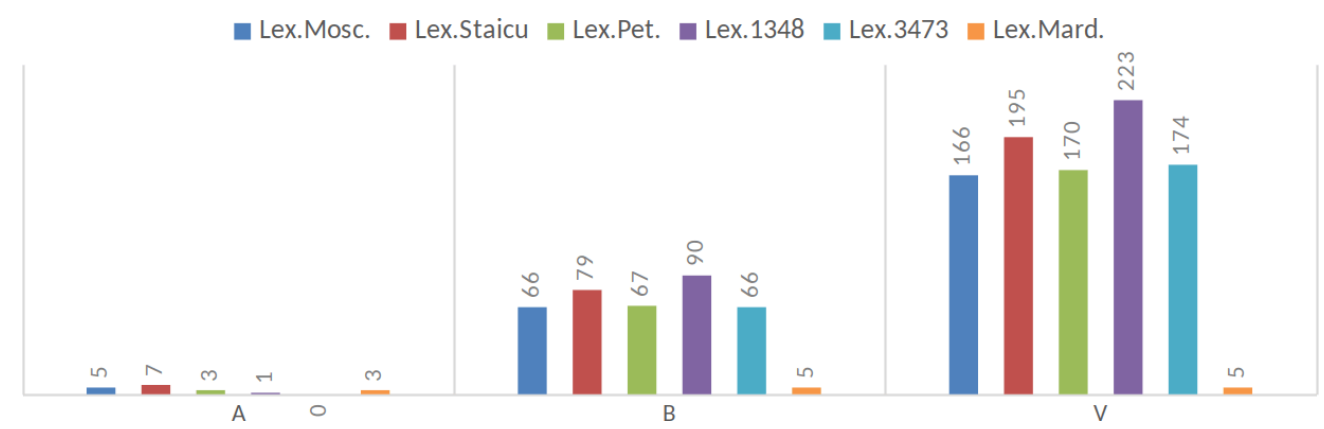

Figura 2: Numărul intrărilor în plus față de Lex.Ber.

Desigur, este necesară și o privire diferențiată asupra inventarelor din cele două (de fapt, trei; lista de nume comune este urmată de una suplimentară) liste din Lex.Ber., care deocamdată nu poate fi generată automat. Analiza intrărilor a arătat că cea mai mare fidelitate este manifestată faţă de lista cuvintelor comune, în timp ce din lista a doua (nume proprii și termeni savanți, împrumutați) sînt selectate cele mai cunoscute; de exemplu, dintre numele proprii sînt selectate cele de călugări, care ar fi putut fi folosite ca nume de botez, și numele zeilor celor mai cunoscuți.

Există două modalități de a introduce noi intrări în lexicoanele românești: (a) intercalat, între intrările provenite din Lex.Ber.; (b) în calup, la finalul intrărilor provenite din Lex.Ber. Aceste modalități sînt caracteristice pentru tipuri diferite de cuvinte.

(a) Intrările intercalate între cele preluate din Lex.Ber. sint în număr redus. Cea mai mare parte a lor este constituită din completări de paradigme, la care se adaugă cîteva substantive din fondul lexical comun. Aceste intrări sînt comune sau tuturor lexicoanelor, sau unora dintre ele (vezi în tabelul de mai jos).

\begin{tabular}{|c|c|c|c|}
\hline Lex.Ber. & \multicolumn{3}{|c|}{ Lexicoanele românești } \\
\hline \multirow[t]{6}{*}{ вра́чүүса } & Lex.Mosc. etc. & 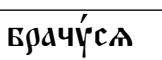 & mă însor (eu) \\
\hline & Lex.Mosc. & Б९дчи́теА & să însoară el \\
\hline & Lex.Staicu & Бөдчи́теА & se însoară \\
\hline & Lex.Pet. & Бөдчи́теА & să însoară el \\
\hline & Lex.3473 & & \\
\hline & Lex.1348 & Бөдчи́тел & să-nsoară \\
\hline \multirow[t]{6}{*}{ 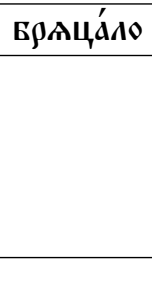 } & Lex.Mosc. etc. & Б९Аца́A0 & sunare, clopoțel \\
\hline & Lex.Mosc. & Бљацца́ю & sun clopoțel \\
\hline & Lex.Staicu & Б९Аца́ю & sun, drăngăiesc \\
\hline & Lex.Pet. & Б९Аца́ю & sunu în clopoțelu \\
\hline & Lex.1348 & Б९Аца́ю & sun un clopoțel \\
\hline & Lex.3473 & Б§Аца́ю & sun clopoțel \\
\hline
\end{tabular}

(b) Intrările din calupuri, de la finalul listelor, se suprapun și ele parțial, cu diferențe de la un lexicon la altul. Conțin cuvinte din fondul comun, unele chiar repetate (vezi comparația din Gînsac \& Ungureanu, 2019, p. 255-257). Felea (2021) presupune, raportîndu-se la Lex.Staicu, că ele se datorează valorificării a încă unei surse, un lexicon slavon de tip 2 (neordonat alfabetic).

\subsection{La nivelul structurii intrărilor și al datelor furnizate}

În lexicoanele românești, intrările sînt modificate faţă de sursă în ceea ce privește tipul informațiilor transmise. Aceste modificări sînt, cele mai multe, de reducere a conținutului informaţional și a tipului de informații, dar în unele cazuri (mult mai rare) intrarea este amplificată prin comparație cu Lex.Ber. 


\subsubsection{Definiţii reduse in raport cu sursa}

Procedeele de reducere sînt de diverse tipuri: omitere a informațiilor, omitere a unor echivalenți, sinteză.

(a) Accá

Lex.Ber.: Lepton, obol, gr.: '̊̀r r'́ra, monedă, heller, 6 bani polonezi sau 2 șalăi. La atenieni obolul valora 6 monede de cupru, iar moneda de cupru - 7 leptoni. Numa, primul rege roman după Romulus, a poruncit să se facă ași și oboli din fier și din cupru, deoarece pînă la el moneda romană era din ceramică și din piele ${ }^{2}$.

Lex.Mard.: fileariu, mangăr.

Lex.Staicu: banii. Fost-au și niște bani de lut și de piale la Rim de s-au chiemat assarii.

Lex.Mosc.: banul. Fost-a $u$ și nişte bani de lu $t$ și de piiale la Rîm de s-au chemat assarii.

Lex.Pet.: banul. Fost-a $u$ și niște bani de lut și de piiale la Rîm de s-au chemat assarii.

Lex.3473: -

Lex.1348: banul. Fost-a $u$ și niște bani de lut și $d[\mathrm{e}]$ piiale la Rîm de s-a $u$ chemat assari.

În Lex.Ber., echivalenții în ruteană sînt urmați de un echivalent în greacă și de precizarea valorii monedelor respective atît în perioada antică, cît și în cea contemporană. Urmează informații istorice despre materialul din care erau confecționate monedele. În lexicoanele românești se observă două direcții: (1) Lex.Mard. indică doi echivalenți (unul din maghiară și unul din turcă, ambele avînd în DLR atestări din Muntenia), omițînd celelalte explicații; (2) celelalte lexicoane au o structură total diferită a intrării, bazată pe sinteza informațiilor din Lex.Ber. În Lex.Mosc., intrarea apare și două rînduri mai sus, doar cu definiția banul.

(b) Aрті́їій

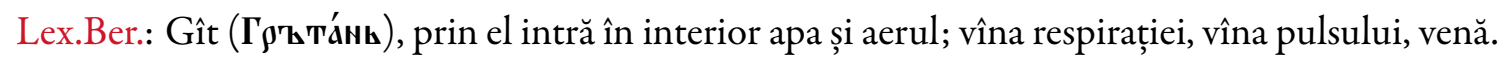
Omil. apost. 1222.

Lex.Mard.: grumazul prin care întră înlăuntru apa și văzduhul

Lex.Staicu grumazii

Lex.Mosc.: grumazii

Lex.Pet.: grumazii

Lex.3473: -

Lex.1348: grumazii.

Lex.Ber. indică un echivalent și o explicație, după care alte sensuri și o trimitere bibliografică. Lex.Mard. este cel mai apropiat de definiția din Lex.Ber. (echivalent + explicație); celelalte indică numai echiva-

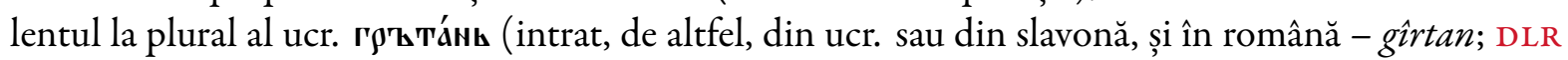
indică un etimon slav și îl atestă la Cantemir, s.v. gîtlej). Văzduh din Lex.Mard. este o preluare directă din sursă (вода и в 'ъ̌̉AŶ̀), unde are sensul 'aer'; DLR nu consemnează sensul 'aer' al lui văzduh.

\subsubsection{Definiții amplificate in raport cu sursa}

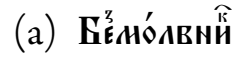

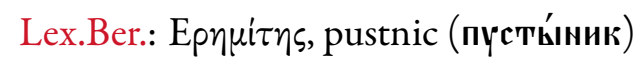

Lex.Mard.: negîlcevitoriu, pustinic

Lex.Staicu: pustinnic, ce petreace fără gîlceavă

Lex.Mosc.: sihastru, cela ci petreace făr $[\breve{a}]$ de gîlceavă

Lex.Pet.: sihastru, cela ce petreace fără de gîlceavă

Lex.3473: sihastru, cela ce petreace fără gîlceavă

Lex.1348: 一.

\footnotetext{
${ }^{2}$ Definițiile din Lex.Ber. au fost traduse de Cecilia Maticiuc și Ion-Mihai Felea, ca parte a proiectului eRomLex.
} 
Lexicoanele românești nu reproduc echivalentul în greacă. La echivalentul pustnic / sihastru se adaugă

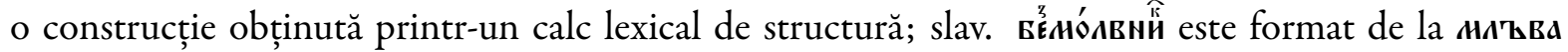
'tumultus' (Miklosich, s.v.), la care se adaugă prefixul privativ Eє3-. Rom. pustinnic din Lex.Mard. și Lex.Staicu este justificat contextual, alegerea sa fiind determinată de termenul din sursă; nu e clar de ce în unele lexicoane este înlocuit cu sihastru, însă astfel de cazuri, discutate contextual și comparativ, ar putea servi la determinarea zonei de proveniență a autorilor și chiar la stabilirea paternităților.

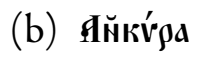

Lex.Ber.: ancoră (cf. Popowicz, s.v. котва) + trimitere bibliografică (Nr. Mth. 23)

Lex.Mard.: cătușe la corabie

Lex.Staicu: mîțele corăbiei ce aruncă în mare cu funile și țin corabiia

Lex.Mosc.: mîțele corăbiei ce aruncă în mare cu funile și țin corabiia

Lex.Pet.: mîțile corăbii ce aruncă în mare cu funile și țin corabiia

Lex.3473: -

Lex.1348: mațele corăbie[i] ce aruncă în mare cu funil[e] și țin corabiia.

Lexicoanele românești se îndepărtează de definiția din sursă, renunțînd la trimiterea bibliografică, pe de o parte, și, pe de alta, încercînd să dea o descriere funcțională a obiectului denumit de cuvîntultitlu. Lex.1348 pare o copie după unul dintre celelalte, din cauza erorii de copiere (mîțele - mațele). În DLR, pentru sensul 'ancoră' al lui mîţă se trimite la atestarea din Lex.Staicu; de asemenea, la NTB (1648) și, regional, la atestări din Banat, Transilvania (dar exemplele arată că termenul denumește pe tot teritoriul românesc diverse unelte sub formă de cîrlig).

\section{(c) Васи́иїй}

Lex.Ber.: ц厶́ąz (+ trimitere bibliografică)

Lex.Mard., Lex.Mosc., Lex.Pet., Lex.3473: împărat (cu diverse variații grafice)

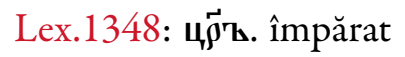

Lex.Staicu: cel dăstoinic a fi întru în polate înpărătești.

Lex.1348 preia și echivalentul din Lex.Ber. (sau din eventualul intermediar pierdut a cărui existență o presupunem). Lex.Staicu dă o explicație a sensului figurat al termenului, nejustificată prin nimic de definiţia din sursă.

(d) Гopà

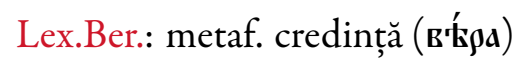

Lex.Staicu: măgură, munte

Lex.Pet.: măgură, muntele

Lex.1348: munte, măgură

Lex.3473: metaf. măgură, credință, munte

Lex.Mard.: muntele, credința.

Unele definiții din Lex.Ber. conțin explicații considerate metaforice și marcate prin metaf(or). (Rozumnyj, 1968, p. 38-39), de exemplu: Г'́̌csи: „vioară [...]; metafor., adică simbolic înseamnă 'gînd’”. În cazul evidențiat mai sus, două dintre lexicoanele românești (Lex.3473, Lex.Mard.) echivalează explicația в'É $\rho a$ 'credință', preluată ca atare și în Sparwenfeld (Lexicon Slavonicum, 1684-1705); toate lexicoanele, în schimb, adaugă explicația 'munte, deal' (Miklosich, s.v. ropa), care lipsește în sursă. 
(e) Г४४ч'́⿴\zh11

Lex.Ber.: doar indicații bibliografice

Lex.3473: şopîrle

Lex.Staicu: șopîrle

Lex.Mosc.: șopîrle.

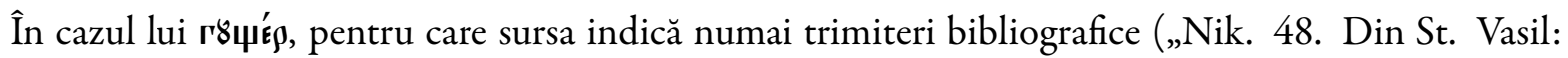
Despre feciorie”), cele trei lexicoane slavo-române care îl preiau adaugă și explicația.

\title{
(f) Алокаитї̈а́н'
}

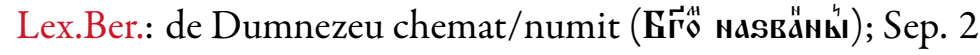 \\ Lex.Pet.: numele lui Dumnezeu \\ Lex.1348: numele lui Dumnezeu \\ Lex.Staicu: numele lui Dumnezeu \\ Lex.3473: numele lu $i$ Dumneze $u$, sa $u$ de Dumneze $u$ chema $t$ \\ Lex.Mard.: - .
}

Pentru Аıюклитї̈́́' ‘, în afară de explicaţia din sursă, „de Dumnezeu chemat”, pe care o înregistrează fidel numai Lex.3473 (care conține definiții mai ample), lexicoanele slavo-române propun echivalarea „numele lui Dumnezeu”, probabil o interpretare aproximativă a explicației din Lex.Ber. Aceasta și faptul că explicaţia preluată de sursă se află pe locul al doilea în Lex.3473 ar putea fi un indiciu pentru faptul că acest lexicon a copiat întîi unul dintre celelalte dicționare, după care l-a colaționat cu sursa.

(g) Якрі́ды

Lex.Ber:: Iarbă sau plantă a cărei rădăcină [se răsucește] împrejurul altor plante, preluîndu-le

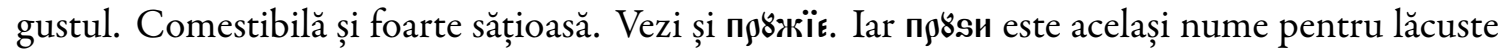
(конники), după asemănarea cu floarea și rădăcina acelei plante. Despre aceasta citește cartea intitulată „Cornucopia”. Apoc. 9:3. Ecl.12:5 și Пр8ги Lev. 11. Omonim al unei plante, vietate zburătoare de diverse tipuri.

Lex.Mard.: mugur sau lăcuste

Lex.Mosc.: Iaste o iarbă în pustiile Iordanului cărie rădăcina trage dulceaţa tuturor erbilor care vor fi aproape de ea și la mîncare iaste dulce și ține sațiul. Iar floarea-i iaste aseamene lăcustei. Rădăcina aceștii erbi a $u$ mîncat și Ioan $\mathrm{Cr}[\mathrm{a}]$ stitel.

Lex.Staicu: iaste o iarbă în pustiile Iordanului a căriia rădăcină trage dulceața altor erbi de pe împrejur și la mîncare iaste dulce și ține sațiu. Iar floarea ei iaste aseamenea lăcustei. Aceasta se zice și prujie, iară prudzite-s acelaş[i] nume sau connichi lăcuste, pentru asemănarea florii și rădăcinii aceii erbi. De aceasta să cetești cartea ce se chiamă Cornucopie. Apoc. Tl. glav. 9. Eclisias. 12.

Lex.Pet.: iaste o iarbă în pustiia Iordanului căriia rădăcina trage dulceața tuturor erbilor care vor fi aproape de ea și la mîncare iaste dulce și ține sațiul. Iar flo[a]rea îi iaste aseamene lăcustei. Rădăcina aceștii erbi au mîncat și Ioan Predtecea.

Lex.3473: -

Lex.1348: Iaste o iarbă în pustiia Iordanului căriia rădăcina trage dulceaţa tuturor erbilor $[\ldots]^{3} \mathrm{fi}$ aproape de [...] mîncare iaste dulce și ține sațiu. Iar floarea ei iaste aseamenea lăcustei. Rădăcina aceștii erbi au mîncat și Ioan Preadtecea.

$\mathrm{Cu}$ excepția Lex.Mard., care indică numai cei doi echivalenți posibili (așa cum rezultă din definiția din sursă), lexicoanele românești prezintă mici diferențe în raportarea informaţiilor: trimiterile bibliografice pot fi reținute (Lex.Staicu) sau omise (celelalte lucrări), la fel și informațiile de ordin lingvistic

\footnotetext{
${ }^{3}$ Ilizibil în manuscris.
} 
furnizate de Berînda (alte denumiri pentru aceeaşi plantă sau dublul sens al unui termen și justificarea lui prin raportare la realitate). Lex.Mosc., Lex.Pet. și Lex.1348 aduc o informație suplimentară, despre prezența plantei în imaginarul creștin (împrumutată probabil dintr-o hagiografie sau din propriile cunoștințe anterioare; confuzia referitoare la referentul termenului care a denumit mîncarea lui Ioan Botezătorul în pustiu persista în traducerile epocii, cf. $\mathrm{Bв}, M t, 3,4$ : „hrana lui era vlăstare și miiare sălbatică”; NTB, $M t, 3,4$ : „mîncarea lui era lăcuste și miiare sălbatică”); probabil că informația era prezentă și în Lex.3473. Grupul celor trei diferă prin numele cu care îl desemnează pe Ioan Botezătorul.

Astfel de tratamente diferite ale informațiilor din Lex.Ber. indică filiațiile dintre lexicoane și, poate, utilizarea unei alte surse lexicografice. În orice caz, aceste definiţii arată că alcătuitorii lexicoanelor românești nu sînt simpli copiști, ci că modifică ceea ce copiază, în funcție de ce consideră ei că este informație relevantăiar aceste informații relevante pot da indicații despre scopul alcătuirii acestor lexicoane.

\section{Concluzii}

Cazurile în care autorii lexicoanelor slavo-române amplifică definițiile sînt, desigur, mult mai puține decît cele de reducere; asupra inventarului de intrări se intervine, însă, consistent. Inovațiile în ceea ce privește definițiile (în ambele direcții, atît reducerile, cît și amplificările) oferă indicații despre interesele autorilor români, în afară de faptul că pun în lumină filiațiile dintre ele.

Ediția comparativă a lexicoanelor pune în evidență relațiile dintre acestea. Chiar și din exemplele indicate se vede că Lex.Mard. constituie o redacție aparte. În privința celorlalte, lucrurile nu par chiar așa de clare, dar un studiu statistic la nivelul întregului material va putea furniza observații interesante.

Ediția digitală presupune, după cum am văzut, şi avantaje, și dezavantaje. Pentru comparația exhaustivă a lexicoanelor, însă, ea este un instrument extrem de util, pentru că facilitează vizualizarea simultană a intrărilor. De asemenea, va fi un instrument util pentru lexicografi (care pot identifica aici noi lexeme, forme și atestări), pentru cei care studiază istoria limbii și pentru viitoare alte corpusuri digitale sau dicționare electronice.

\section{Bibliografie}

\section{A. Sigle}

Anon.Car. = Dictionarium Valachico Latinum. Primul dicționar al limbii române [c. 1650], studiu introductiv, ediție, indici și glosar de Gh. Chivu, Editura Academiei Române, București, 2008.

Bв = Biblia, ádecă Dumnezeiasca Scriptură ale cei Vechi și ale cei Noao Lêge [...], tipărită întîia oară la 1688, în timpul lui Șerban Vodă Cantacuzino, Domnul Țării Românești, în Munteanu, E. (coord.), Monumenta lingux Dacoromanorum. Pars XXIII. Novum Testamentum I: Evangelia, Editura Universității „Alexandru Ioan Cuza” din Iași, 2015.

Corbea $=$ Teodor Corbea, Dictiones Latina cum Valachica interpretatione, ediție de Alin-Mihai Gherman, Clusium, ClujNapoca, 2001.

DLR = Dicționarul limbii române, tomurile I-XIX (ediție anastatică), Editura Academiei Române, București, 2010.

DVs = Dosoftei, Viața și petreacerea svinților, Iași, 1682-1686, text îngrijit, notă asupra ediției și glosar de Rodica Frențiu,

Editura Echinox, Cluj, 2002.

Lex.Ber. = Pamvo Berynda, Leksikon slavenorosskij i imen tl'kovanïe, Kiev, 1927 (Kutein, 21653) [online].

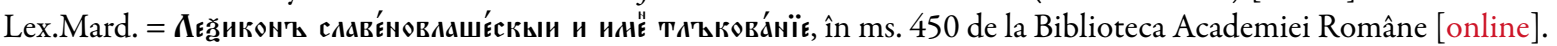

Lex.Mosc. = Lexicon slavo-român, Arhiva Rusă de Stat a Documentelor Vechi (Moscova), ф. 188, оп. 1, ч. 2, p. 491.

Lex.Pet. = Lexicon ce să zice cuvinte pe scurt alease din limba slovenească pre limba rumînească diialectică tîlcuite, Biblioteca

Națională a Rusiei, Sankt Petersburg, cota Q.XVI.5-Славяно-молдавский словарь, 100 мистов, составлен в 1695 году.

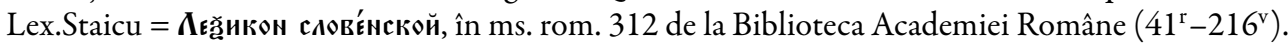

Lex.1348 = Lexiconul din ms. rom. 1348 de la Biblioteca Academiei Române (ff. 1-84v); fără pagină de titlu.

Lex.3473 = Lexiconul din ms. rom. 3473 de la Biblioteca Academiei Române (ff. 1-369 v); fără pagină de titlu.

Miklosich $=$ Franz Miklosich, Lexicon Paleoslovenico-Greco-Latinum, G. Braumueller, Vindobonæ, 1862-1865 [online].

NTB = Noul Testament sau Impăcarea cu Leagea Noao a lui Iisus Hristos Domnului nostru, izvodit cu mare socotință den izvod

grecescu și slavonescu pren limbă rumânească [...], Bălgrad, 1648 [ediție modernă: Editura Episcopiei Ortodoxe Române a Alba Iuliei, 1988].

Popowicz = Emilian Popowicz, Ruthenisch-Deutsches Wörterbuch, Langenscheidtsche Verlagsbuchhandlung, Berlin, 1911. 
Sparwenfeld = Johan Gabriel Sparwenfeld, Lexicon Slavonicum [1684-1705], vol. I, edited and commented by Ulla Birgerard, Upsalla, 1987.

\section{B. Literatură secundară}

Bogdan, I. (1891). Un lexicon slavo-român din secolul XVII, în „Convorbiri literare”, XXV, p. 193-204.

Ciobanu, Șt. (1914). Славяно-румыняскій словарь библіотеки Московскаго Общества Исторіи и Аревностей o. 240, în „Русскій фимологическій вестникъ, 71 (1), p. 75-88.

Crețu, G. (ed.) (1900). Mardarie Cozianul. Lexicon slavo-românesc și tîlcuirea numelor din 1649, Edițiunea Academiei Române, Institutul de Arte Grafice „Carol Göbl”, Bucuresci.

Felea, I.-M. (2021). Lexiconul Staicu in raport cu cele din familia Berînda: ortografie și alcătuire, în „Diacronia”, 13, 13 iun., art. A181, Crossref.

Gînsac, A.-M. \& Ungureanu, M. (2018). La lexicographie slavonne-roumaine au XVII' siècle. Adaptations roumaines d'après le Leksikon slavenorosskij de Pamvo Berynda, în „Zeitschrift für romanische Philologie”, 134 (3), p. 845-876, Crossref.

Gînsac, A.-M. \& Ungureanu, M. (2019). Lexiconul de la Moscova in raport cu celelalte lexicoane slavo-române din secolul al XVII-lea, în „Philologica Jassyensia”, XV (2), p. 245-258.

Kałužniacki, E. (1894). Ueber ein Kirchenslavisch-rumänisches Vocabular, în „Archiv für slavische Philologie”, XVI, p. 46-53.

Mihăilă, G. (1972). Contribuții la studiul lexicografiei slavo-române din secolul al XVII-lea, în Contribuţii la istoria culturii și literaturii române vechi, Editura Minerva, București, p. 307-324.

Rozumnyj, J. (1968). Proper Names in Pamvo Berynda's "Leksikon slavenoroskij i imen tlkovanie" of 1627, thesis presented to the Faculty of Arts of the University of Ottawa through the Department of Slavic Studies, Ottawa, University of Ottawa.

Seche, M. (1966). Schiță de istorie a lexicografiei române, vol. I: De la origini pînă la 1880, Editura Științifică, București.

Stankiewicz, E. (1984). Grammars and Dictionaries of the Slavic Languages from the Middle Ages Up to 1850: An Annotated Bibliography, Mouton Publishers, Berlin, Crossref.

Strungaru, D. (1960). Gramatica lui Smotrițki şi prima gramatică românească, în „,Romanoslavica”, IV, p. 289-307.

Strungaru, D. (1966). Inceputurile lexicografiei române, în „Romanoslavica”, XIII, p. 141-158.

Tagliavini, C. (1927). Un frammento di terminologia italo-romena ed un dizionarietto geografico dello Stolnic Constantin Cantacuzino, în „Revista filologică", I, p. 167-184.

Tagliavini, C. (ed.) (1930). „Lexicon Marsilianum”, dizionario latino-romeno-ungherese del sec. XVII, Cultura Națională, București. 